International Journal of Social Science And Human Research

ISSN(print): 2644-0679, ISSN(online): 2644-0695

Volume 04 Issue 08 August 2021

DOI: 10.47191/ijsshr/v4-i8-16, Impact factor-5.586

Page No: 2073-2077

\title{
An Investigation of Distance Teaching: Perceptions, Practices and Perspectives
}

\author{
Dr. Ziani Melouka ${ }^{1}$, Dr. Brahmi Mohammed ${ }^{2}$ \\ ${ }^{1}$ Faculty of foreign languages.University of Mostaganem,Algeria \\ ${ }^{2}$ Faculty of Foreign languages. University of Tiaret, Algeria
}

\begin{abstract}
The present study is an investiagtion of distance teaching as an alternative to in-person classes during a lockdown. The study aims at unveiling the teachers and students' perceptions and attitudes towards e-teaching/learning during a pandemic crisis. As an alternative to face -to face interviews with the teachers and the students because of the sanitary conditions, the tools have been adapted to existing conditions. To obtain data, two tools have been used online, a semi- structured interview with (n 51) master students and a lickert scale questionnaire for (n 18) teachers in the department of English in the university Abdelhamid Ibn Badis in Algeria.Findings revealed the reluctance in the exclusive use of distance teaching by the majority of teachers and the students. The great majority of them also prefers in person classes. This is justified by technical difficulties, lack of comprehension, poor internet flow and a lack of training.
\end{abstract}

KEYWORDS: Attitude, Distance Teaching, Perceptions, Practices

\section{INTRODUCTION}

The educational field, like many other fields is affected by social phenomena. Inadequate social factors, natural disaters or pandemies affect the well-being of educational settings. The corona virus, also known as COVID-19, has taken the world by storm and has impacted all fields ; medecine, economy, industry and education. Consequently, schools and universities have been forced to vacate the formal settings and both students and teachers have been asked to follow virtual classrooms to ensure the safety of the academic year. The present study aims at answereing the following questions :

a. What are the teachers and the students' perceptions and attitudes towards e- teaching / learning ?

b. What is the teachers and the students' attitudes towards distance teaching ?

c. Which difficulties do both teachers and students face in distance instruction?

In order to find valid answers to the aformentioned questions, we assume that the majority of teachers and students may not be ready to teach and learn online and this may be due to a lack of training and avalability of e-equipements.Accordingly, they may have a negative attitude towards online instruction.

\section{ONLINE LEARNING : THE DECAY OF THE TRADITIONAL CLASSROOM?}

Technology has become ubiquitous in our everyday life. Therefore, interest in technology for educational purposes is not new and the introduction of technological tools in learning has become predominant. Indeed,the use of ICTs (Information and Communication Technologies) have witnessed an interest in order to cope with the requirements of the twenty first century. The contribution of technology in the classroom and outside it aims at making learning successful and teaching more effective. Therefore, research and studies have been numerous to investigate for the latest uses among pedagogists within the classroom and outside it, among learners and teachers, as well. The use of technology for learning purposes in informal setting, is becoming more and more predominent and providing learners opportunities to learn away from formal settings. «The terms e-learning and online learning are often used intechangeably, although e-learning can encompass any form of telecommunications and computer-based learning, while online learning means using specifically the Internet and the web» (Bates ,2005 p8).In Algeria, the use of technology for pedagogical purposes has been encouraged both by the ministry of education and the ministry of higher education. The teachers are asked to include ICTs in their teaching and encourage their students to use them. Accordingly, the use of computers, projectors, cellphones, etc are introduced in the formal teaching settings by a great number of teachers.

The transition from traditional chalkboard and overhead projector instruction into computer-aided presentations was innovative.Innovative teachers use new technology to incorporate tools like tablets, computers and mobile devices to offer learners a more interactive experience. Teaching online, according to Howell (2005 p1) means " altering the ways in which we conceive for our work as teachers.It means rethinnking our views and abilities. It means developing new knowledge about teaching and media, 


\section{An Investigation of Distance Teaching: Perceptions, Practices and Perspectives}

new forms of pedagogy, and new communication patterns » Indeed, Because of the very peculiar conditions of online teaching and the absence of face-to-face contact, the teacher must consider the virtual conditions and adopt a more appropriate methodology which emphasizes the generation of learners' knowledge. This latter, based on a constructivist view puts less emphasis on the teacher and more emphasis on learner. Constuctivism challenges students to make their own uses of information and data placed before them (Bach et al, 2006 p137). Moreover, when students interact with teachers and peers, they gain more practical experience and retain more information from a class.

\section{DISTANCE TEACHING : ARE WE READY FOR CHANGE ?}

Social distancing, an unusual concept has emerged since the appearance of Covid 19 in 2020.The virus has made the whole world preoccupied by the impact of the sanitary pandemic situation on the people. The very unusual and unknown spread of the virus has obliged the World Health Organization take some decisions, the confinement of people was crucial in order to reduce contamination. As a consequence, schools, universities, firms and conpanies, all decided on the reduction of their staff and online work was an alternative to in-person work. Algeria, like all the other countries affected by this virus, took the same decisions, and online work is required in order to gain partial work and avoid a complete handicap of its institutions. "Teaching online is a form of change that involves our instructional realities, forms, and attitudes. When faced a specific change, such as the kind that teaching online, inevitably brings, it can be useful to reflect on what is at hand before making a decision about whether to proceed with that change »(Howell, 2015p15)

Academically, the change implies that teachers and learners interact via social networks as an intermediate alternative to in- class learning. At university level, the ministry of higher education and research recommended the teachers to upload their lectures on an electronic platform. Algerian Universities and schools, like many international ones, have been closed for a compulsory leave to avoid any spread of the Covid-19 virus among teachers and their learners .Distance teaching as an alternative to classical or in-class teaching has been introduced as a remedial solution to the closure of academic institutions. At the same time and in order to avoid any academic disturbance, the teachers are asked to deliver their lectures on an electronic platform and at the same time the students have been asked to follow their teachers' lectures online. The teachers are provided a user name and password and they have to upload their lectures regularily, respecting the syllabus and the objectives of their course. «Using the technologies that we need to teach online necessarily changes our experiences, or at least our attitudes toward them, and this alteration may be positive or negative, depending on the contexts and specific changes » (Howell, 2015 P14). Yet, distance education, a dynamic and ditinct form of education (Bates, 2005) requires careful attention as regard to the identification of learning objectives and outcomes.For such reasons, adequate training and proper material selection are crucial.

\section{METHODOLOGY}

The present study took place during the lockdown period of 2020.The study investigates the teachers and students' practices, perceptions and attitudes towards distance education. Two tools were used to gather data ; a questionnaire and a semi-structured interview. Because of the pandemic conditions and the confinement, the questionnaire was sent via email to (n32) teachers from the department of English in the university of Mostaganem. Unfortunetely, only (n18) teachers responded to the online questionnaire. This may be representative of the teachers' attitude towards electronic devices use or the electronic questionnaires. Also, the study itself was at the beginning of the confinement, that was the purpose of the researcher, a very new experience of teachers and they might not have been ready enough to interact electronically. The objective was to identify the perceptions and attitudes of the teachers The respondents had to answer a 30 lickert scale questionnaire (Test of e-Learning Related Attitudes (TeLRA) scale) in order to investigate their perceptions and their attitudes towards electronic teaching. The statements vary from strongly disagree to strongly agree. The teachers age and speciality varried. The majority was female since the department includes 45 women and only two men. Eight teachers are aged between forty and sixty five years old. Twenty four others are aged between twenty eight and forty years old. The questions investigated the teachers' experiences with the use of technology, their skills as well as their difficulties in using technology devices. Similarly, in the same conditions, the students' semi- structured interview was online and ( $\mathrm{n}$ 51) master students had to answer questions about their experiences with online learning. Because of the difficulty to get in touch with the students who were unfamiliar to the researcher, an intermediate student helped gathering data from the students. The interview questions investigated the students' experiences and difficulties with online learning.

\section{RESULTS AND DISCUSSION OF FINDINGS}

As an answer to the recommendations of the ministry to upload their lectures on the Algerian platform, out of 98 only 26 lectures have been uploaded up to April 4 th 2020 in the department of English in the university Abdelhamid Ibn Badis.That is 26.53\%. Ten days later, out of 98 lectures, 61 lectures have been put online.That is $26.24 \%$.By May 1st, almost all teachers introduced their lectures and the pedagogical supports on the national platform. The study, though quantitative is qualitative in scope ; the aim was to trigger for the practices, difficulties and challenges that both teachers and their students meet in distance teaching. The thirty 


\section{An Investigation of Distance Teaching: Perceptions, Practices and Perspectives}

statements unveil the teachers' perceptions and attitudes towards the use of computers and online teaching. On the other hand, the students' skills, experiences, and access are questionned.

\subsection{Perceptions \& Attitudes}

As far as the perceptions are concerned, the data obtained revealed that the majority of teachers agree on the importance of the integration of tehnology in learning and teaching and have a positive attitude towards e-learning. Almost all teachers answered positively to the use of electronic devices in teaching and find it interesting. Yet, most of them find it difficult and uncomfortable to read electronic materials. In addition, the great majority of the teachers believed that e-learning improves the quality of teaching. Also the findings reflect the teachers' attitude towards electronic devices, In fact, almost all of them enjoy teaching with computers. Paradoxically, half of the teachers said they find it easier to use electronic materials whereas the others find it difficult.Besides, the majority of the teachers believe that e-learning is less learner- centred than face-to- face learning. Similarly, the great majority of the students $(58.82 \%)$ did not have any web-based instruction and they had never followed online courses.

\subsection{Access}

Access to technological devices is a serious issue for many people who for a reason or another lack the opportunity to having an adecquate device or internet access.Financial difficulties may be the core difficulty minimizing teachers and students' access to technology as it has been demonstrated by the majority of the teachers who avowed the high cost of technological devices. Besides, those living in remote areas may be confronted to very poor internet flow, making their online accessibility difficult if not impossible. Others, unfortunately, the majority, admitted their difficulties in manipulating technological devices. . Besides, $(56.86 \%)$ of the students said they had difficulty to internet access and (54\%)said they prefer face to face teaching. This may justify the reluctance of some teachers and students to online teaching and learning.

\subsection{Skills}

The study revealed that some teachers are still pessimistic about the use of technology in the Algerian classroom. They say that they are not ready and properly equipped to use technological tools in the classroom. This may be due to a lack of appropriate training. Moreover, others believe that they are not able to use new technologies for pedagogical purposes and are faithful to conventional teaching. As far as learning and comprehension are learning, the obtained data revealed that the students had difficulties in understanding the content of the lectures. This may be due to the absence of interaction between teachers and their students.

When asked whether teachers intend to reteach the content they uploaded online, almost all of them agreed to do so. Almost all of the teachers avowed that their students did not react to their teachers' lectures this justifies the the students' answers concerning face to face learning. In fact, all of them prefer in person classes. The students may not have at home internet access or a smart device. This may hinder their access to online lectures and consequently may not be able to follow the instructions of their teachers. This may explain their decision to reteach the online content. Obviously, both teachers and students perceive online education as necessary. Yet, technical troubles and poor access affects their attitudes towards online instruction. Thus, unless the technological means and conditions are favorable to distance education, both teachers and students apprehend to be confronted to those conditions, in fear of misconduct and failure.

\section{CONCLUSION}

The ubiquitous use of technology in our lives, in general and in education more precisely, is no more questionnable. In fact, the twenty-first teachers and learners practices have been altered by the use of technological devices in both teaching and learning. That transition from traditional in- person teaching/learning was not a choice in many circumstances but a compulsory fact as it is the case nowadays, during the pandemic crisis which generated a general lockdown. Accordingly, new and uncommon, for many of us, teaching methodolgies have been adopted and online courses have seen light.The transition and change are not easy for most of time and the unknown is usually scary. The present study has demonstrated that the teachers and students in the department of English in the university of Mostaganem are still faithful to classical face to face instruction and reluctant in teaching and learning online and this is mainly due to their lack of training and the poor quality of technological devices .Besides, we can say that the negative attitude towards online instruction may pertain to psychological issues related to the pandemic crisis. Yet, what makes perfect is practice as the proverb says and those apprehensions will certainly disappear and leave space for comfort and self confidence. Clearly, distance teaching, in spite of its specificities, is as a dynamic process which requires careful attention in the identification of learning objectives and appropriate practices. Thus, the challenging perspective for future teachers is adopting online methodology as an ultimate aletrnative to in-class teaching as the prevailing use of technological devices by youngsters is being more and more predominent.

\section{REFERENCES}

1) Bach,S et al ( 2006) .Transforming Learning Methods through online Teaching. In Online Learning and Teaching in Higher Education. 


\section{An Investigation of Distance Teaching: Perceptions, Practices and Perspectives}

2) Bates,T(2005).Technology, E-Learning and Distance Education. ${ }^{\text {nd }}$ Ed.A.W.USA : Routledge

3) Donnelley,R \& Mc Sweeney,F (2009).Applied E-Learning and E-Teaching in Higher Education.UK : IGI Global

4) Howell, C,M (2015). Teaching Online : A Guide To Theory, research, and Practice. USA : Johns Hapkins Univeristy Press

5) Kisanga, D. H \& Ireson, G.Test of e-Learning Related Attitudes (TeLRA) scale: Development, reliability and validity study and Nottingham Trent University, United Kingdom.In International Journal of Education and Development using Information and Communication Technology (IJEDICT), 2016, Vol. 12, Issue 1, pp. 20-36 .

6) Lehman R,M \& Conceiçao ,S (2010). Creating a Sense of Presence in Online Teaching.How to «BE THERE » For Distance Learners.USA : John Wiley\& Sons, INC

7) Motteram, Gary 2013. Innovations in learning technologies for English language teaching. British Council 2013 .London SW1A 2BN, UK www.britishcouncil.org

8) Pim, Chris.2013 Emerging technologies, emerging minds: digital innovations within the primary sector.IN Innovations in learning technologies for English language teaching. ed by,Gary Motteram. British Council 2013 .London SW1A 2BN, UK www.britishcouncil.org P15-42

9) Slaouti Diane et al (2013).Technology and adult language teaching, In Innovations in learning technologies for English language teaching. ed by,Gary Motteram. British Council 2013 London SW1A 2BN, UK www.britishcouncil.org Pages 67-82

10) Stanley, Graham (2013). Integrating technology into secondary English language teaching .In, Innovations in learning technologies for English language teaching. ed by,Gary Motteram. British Council 2013 .London SW1A 2BN, UK www.britishcouncil.org.Pages 43-66

11) www.surveymonkey.com/mp/coronavirus-distance

\section{APPENDIX 1}

Test of e-Learning Related Attitudes (TeLRA) Scale

The present survey investigates the teachers' perceptions and attitudes towards e- learning during a pandemic crisis. The present lickert scale includes information about teachers' understanding and attitudes about e-learning. Your opinion is important in this study. Do not think too long about each statement. It takes you about 10 minutes to complete. For each statement, put a tick ( P ) to show your level of agreement; Strongly Disagree, Disagree, Agree, and Strongly Agree. Do not tick across two boxes.Thank you

\begin{tabular}{|l|l|l|l|l|l|}
\hline & Statements & $\begin{array}{l}\text { Strongly } \\
\text { disagree }\end{array}$ & Disagree & Agree & Strongly agree \\
\hline 1. & $\begin{array}{l}\text { E-learning is very economical for educational } \\
\text { institutions to adopt. }\end{array}$ & & & \\
\hline 2. & $\begin{array}{l}\text { I believe using e-learning will improve the quality of } \\
\text { my work. }\end{array}$ & & & & \\
\hline 3. & Computers make work more interesting & & & \\
\hline 4. & I prefer reading articles electronically. & & & & \\
\hline 5. & $\begin{array}{l}\text { It is easier to revise electronic educational materials } \\
\text { than printed ones. }\end{array}$ & & & & \\
\hline 6. & $\begin{array}{l}\text { I feel uncomfortable reading a text book on a computer } \\
\text { screen than a physical text book. }\end{array}$ & & & & \\
\hline 7. & I enjoy teaching using computers. & & & \\
\hline 8. & $\begin{array}{l}\text { Delivering a lecture through electronic technologies is } \\
\text { very difficult. }\end{array}$ & & & & \\
\hline 9. & E-learning requires expensive technical support. & & & & \\
\hline 10. & E-learning reduces quality of knowledge attained. & & & & \\
\hline 11. & $\begin{array}{l}\text { Interacting with the computer system is often } \\
\text { frustrating }\end{array}$ & & & & \\
\hline 12. & $\begin{array}{l}\text { A face-to-face method is more learner-centered than E- } \\
\text { learning methods. }\end{array}$ & & & & \\
\hline 13. & $\begin{array}{l}\text { I believe using e-learning technologies will improve } \\
\text { my job performance }\end{array}$ & & & & \\
\hline 14. & Communicating through social networks is fun. & & & \\
\hline 15. & $\begin{array}{l}\text { I like reading magazines on new technology } \\
\text { innovations. }\end{array}$ & & & & \\
\hline
\end{tabular}


An Investigation of Distance Teaching: Perceptions, Practices and Perspectives

\begin{tabular}{|l|l|l|l|l|l|}
\hline 16. & Teaching through e-learning is tiresome & & & & \\
\hline 17. & E-learning increases learners' social isolation. & & & & \\
\hline 18. & E-learning technologies are difficult to use. & & & & \\
\hline 19. & Using computer systems requires a lot of mental effort. & & & & \\
\hline 20. & $\begin{array}{l}\text { Discussions on e-learning technologies are } \\
\text { uninteresting. }\end{array}$ & & & & \\
\hline 21. & E-learning will increase teachers' efficiency. & & & & \\
\hline 22. & Working with computers is exciting. & & & & \\
\hline 23. & I like discussing about new e-learning innovations. & & & & \\
\hline 24. & $\begin{array}{l}\text { It will be difficult for me to become skilful in the use } \\
\text { of e-learning tools. }\end{array}$ & & & & \\
\hline 25. & I make errors frequently when using a Computer. & & & & \\
\hline 26. & $\begin{array}{l}\text { E-learning will provide me with better learning } \\
\text { opportunities than traditional means of learning. }\end{array}$ & & & & \\
\hline 27. & I find computer online interaction unexciting. & & & & \\
\hline 28. & $\begin{array}{l}\text { Communicating through electronic mails is } \\
\text { ineffective. }\end{array}$ & & & & \\
\hline 29. & $\begin{array}{l}\text { I intend to reteach the content of the material after the } \\
\text { confinement is over. }\end{array}$ & & & & \\
\hline 30. & $\begin{array}{l}\text { The students have not replied to the electronic content } \\
\text { I uploaded. }\end{array}$ & & & & \\
\hline
\end{tabular}

\section{Appendix 2 Students' inteview}

1. Level

2. Age

3. Sex

4. $\quad$ Do you have easy access to internet ?

5. Have you had any web-based courses ?

6. Have you followed the online lectures ?

7. Do you prefer face to face learning or distance learning ?

8. Which difficulties do you face in online learning ? 